\title{
INVESTIGATOR ISSUE IN FINANCIAL SERVICE CRIME IN INDONESIA
}

\author{
Wahyu Wiriadinata
}

* Lecturer of Faculty of Law, University of Pasundan, Bandung

\author{
Article Info \\ Received : 24 April 2014 | Received in revised form : 20 August 2014 | Accepted : 4 November 2014 \\ Corresponding author's e-mail : wahyuwiriadinata@yahoo.co.id
}

\begin{abstract}
The objective of this paper is to address a question of the effectiveness of Financial Service Authority (Otoritas Jasa Keuangan - OJK) investigators in eradicating financial service crimes in Indonesia. This question arises because in Law on Financial Service Authority there are OJK's investigators with an investigatory authority on OJK crimes, including; banking, capital market, insurance, pension fund, financing institutions, and other financial service institution sectors. Meanwhile, there have been other investigators with an authority to investigate, namely, public prosecutor, police, and KPK (Indonesia's corruption eradicating commission). The result was in a form of juridical aspect and written in a descriptive-analytical form. The conclusion of this paper was as follows: there was an overlapping of authorities between OJK's investigators and public attorney's investigators, police, and KPK, be they in the investigation of general crimes and that of special crimes/corruption. As for the effectiveness of OJK's investigators, it should be proved yet in the future.
\end{abstract}

Keywords :Investigator, Financial Service, Effectiveness, Overlapping

\begin{abstract}
Abstrak
Tujuan dari makalah ini adalah untuk menjawab pertanyaan mengenai efektivitas Otoritas Jasa Keuangan (OJK) dalam memberantas kejahatan jasa keuangan di Indonesia. Pertanyaan ini muncul karena di Undang-Undang OJK ada penyidik OJK dengan otoritas investigasi kejahatan OJK, termasuk; perbankan, pasar modal, asuransi, dana pensiun, lembaga pembiayaan, dan lembaga jasa keuangan sektor lainnya. Sementara itu, ada peneliti lain dengan kewenangan untuk menyelidiki, yakni, jaksa, polisi, dan KPK (korupsi di Indonesia memberantas komisi). Hasilnya adalah dalam bentuk aspek yuridis dan ditulis dalam bentuk deskriptif-analitis. Kesimpulan dari penelitian ini adalah sebagai berikut: ada tumpang tindih kewenangan antara peneliti OJK dan pengacara publik penyidik, polisi, dan KPK, baik itu dalam penyelidikan kejahatan umum dan kejahatan khusus / korupsi. Adapun efektivitas penyidik OJK, itu harus dibuktikan namun di masa depan.
\end{abstract}

Katakunci : Penyidik, Jasa Keuangan, Efektivitas, Overlapping

\section{Introduction}

In attempt to build a national economy that grows stably and steadily, creates a balance across all economic sectors, and provides equitable prosperity to the whole Indonesian people, national economic development program should be realized comprehensively and can drive national economic activities that are far-reaching and across all real sectors. One of the important components in the national economic system is the financial system and all activities that serve an intermediary function 
for various productive activities in national economy.

Economic globalization has created a system that is complex, dynamic, and interrelated between financial sub-sectors, both in products and in institutions. The existence of those financial service institutions that have ownership relations in various financial sub-sectors aggravates the complexity of transactions and interactions between financial service institutions in a financial system.

The many cross-sector problems in financial services, including moral hazard actions, the less than optimal protection of financial service customers, and the disruption of stability in financial system, all compel the establishment of supervisory institution in an integrated financial service sector.

Therefore, a rearrangement of organizational structure of those institutions that implement regulatory and supervisory duties in financial service sectors, including banking, capital market, insurance, pension fund, financing institutions, and other financial service institution, should be conducted in order to achieve a more effective coordination mechanism in dealing with any problems that arise in financial system so as to secure the realization of stability in financial system. The regulation and supervision of the whole financial service activities should be made in an integrated way.

Financial Service Authority (Otoritas Jasa Keuangan / OJK)is needed for all activities of financial service in financial sector to be implemented in an orderly, fair, transparent, and accountable way, and to be capable of realizing a financial system that grows constantly and stably, and capable of protecting customers and community's interests. With these goals, $0 \mathrm{JK}$ is hoped to be capable of supporting national financial service sector so that it would successfully increase national competitiveness. In addition, OJK should be capable of protecting national interests, including among human resource, management, controlling, and ownership in financial service sector, by consistently considering the positive aspects of globalization.

Self-sufficient/independent Financial Service Authority is based on the following principles:

- Independence, which is, being independent in decision making and in implementing the functions, duties, and authorities of $0 \mathrm{JK}$, consistently in conformity with the prevailing legislations.

- Legal certainty, that is, a rule of law principle that prioritizes the bases of legislations and justice in every policy of OJK implementation.

- Public interest, that is, a principle of customers and community defence and protection and general well-being advancement.

- Openness, that is, a principle of being open to people's rights of obtaining accurate, honest, indiscriminative information on the implementation of OJK, by consistently paying attention to the protection of individual and communal basic rights and state secrets, including those secrets that are provided for in legislations.

- $\quad$ Professionalism, that is, a principle that prioritizes merits implementing OJK'S duties and authorities, consistently based on prevailing code of ethics and legislations.

- Integrity, that is, a principle that strictly upholds moral values in each action and decision made in implementing $0 \mathrm{JK}$, and 
- Accountability, that is, a principle that prescribes that each activity and the end result of each activity of implementing OJK should be accountable to public.

In Indonesia, the role of financial service has ever experienced a time period where it supposedly didn't protect the community of financial service users, or even damaged both community and state, as in Bank Indonesia's Liquidity Aid (BLBI) case.

BLBI case is a problem that considerably shook the condition of Indonesian banking and economy and impacted politic and legal issues. The BLBI case, beginning in 1997, involved some top ranking officers, from President Soeharto, Minister of Economy and Industry, Minister of Finance, Minister of State Secretary, Bank Indonesia's Management, and some Parliament Members of 1999-2004 term who covered Economic and Financial field. The case began in August 1997 when Soeharto's administration applied a free floating exchange rate system. People panicked and then bought dollars in large scales. After the government's fund has been drawn to Bank Indonesia, the rates in money markets and deposits rose drastically, because banks struggled in hurry to drain up people's moneys. In September 1, 1997, Bank Indonesia cut SBI rate three times, and then there was a rumor about some large banks that failed in bank clearance and lost in foreign exchange transactions. It caused the confidence level of community on national banks wobbly, and then a rush occurred. Faced with this phenomenon, the government helped healthy banks to overcome their liquidity problems, whereas unhealthy ones were either merged or liquidated. This policy of loan provision is called Bank Indonesia's Liquidity Aid (BLBI). In November 1, 1997, there were 16 banks liquidated, and in December 31, 1997, Bank Indonesia began opening and providing massive funds, around 6 trillion rupiah to those banks that were involved in financial problems. The 600 -trillion BLBI was in fact misused by the receiving banks, so that it became a criminal issue and led to some corruption crime cases that Republic of Indonesia Public Attorney General handled.

Some of the BLBI cases involved big banks whose cases have been decided by courts where the bank's management were found guilty of committing corruption crime. However, the investigations of other cases that involve large conglomerates have been terminated by general attorney.

However, Indonesian Anti-Corruption Community filed a pre-trial against the termination. On May 6, 2008, South Jakarta District Court accepted a petition of pretrial that Indonesian Anti-Corruption Community filed against a letter of termination of investigation (SP3) that General Attorney issued on a BLBI case of Syamsul Nursalim. General Attorney immediately appealed. The issue led to a lingering polemic between law enforcement officers (attorneys, police, and KPK), the government, and politicians in Parliament. This uncertain condition damaged both the customers of financial service (banking) users and the state.

Another case is Bank Century. It began with the failure of the bank in fulfilling a prefund clearance (inter-bank transaction) in Bank Indonesia on November 2008, as admitted by the bank's management. In its admission, Bank Century's management said that the bank was delayed for only 15 minutes in fulfilling a prefund clearance fund of Rp5 billion, which should has been transferred at 08.00 WIB (local time). Therefore, Bank Century's management announced that they had failed in clearance because of a too high intensity of the customers' transactions of inflow and outflow cashes due to the tight liquidity at that time. At the same time, Muliaman D Hadad, Deputy Governor of Bank Indonesia, told that he knew nothing about it. He said all banks, both big and small ones, were at that time under the supervision of BI in order 
for the liquidity problem could be controlled properly. On November 21, 2008, Bank Indonesia Governor Boediono announced that BI, through Financial System Stability Committee (KKSK) had decided the taking over of Bank Century by Saving Guarantor Institution (LPS).

Although Bank Indonesia was aware that the health condition of Bank Century was poor, LPS asked the customers not to panic because the institution would guarantee the entire needs of Bank Century's liquidity by an allocation of Rp1 trillion.

Based on LPS data, an injection of fund that the institution had granted to Bank Century was Rp6.77 trillion in total.

An evidence of erroneousness of Bank Century's management in implementing its operational could be seen more clearly when former Bank Century's CEO, Hermanus Hasan Muslim, was decided as the accused on November 27, 2008. Based on the investigation of police investigator, Hermanus had committed a banking crime. He was found guilty of approving a request of an earlier accused, Robert Tantular.

In fact, Bank Century scandal was not just an internal affair. An allegation of the weakness of supervision and coordination between Bank Indonesia and BapepamLK was evidenced by the surfacing of embezzlement of PT Antaboga Sekuritas's investment fund at Bank Century. The company established in 1989 was indicted by its customers to Supervisory Board of Capital Market and Financial Institution (Bapepam-LK). Some of the company's management had allegedly embellished its investors' moneys. The tentative loss that the investors suffered was Rp233 millions. The loss, according to Police, would likely increase.

The chaos in Antaboga began with a case that occurred in PT. Bank Century Tbk, when the operational of the bank was taken over by LPS. Hundreds of Antaboga came to the company's office. They wanted to draw their moneys invested in reksadana. The reason, the products of investment that Antaboga issued were marketed by Bank Century. Most of Antaboga's customers were Bank Century's customers. They were asked to sign reksadana certificates at Bank Century's office.

In the case of Bank Century, now renamed to be Bank Mutiara, some of the bank's management has been punished. However, other cases that incurred larger losses to the state and involved some high ranking officers and businessmen of Indonesia, have not been handled completely yet.

The suspected in the cases of money laundering that damaged the customers of financial services, such as DhanaWidyatmika, was threatened by Articles 1,3 , and 4 of Law No. 8/2010 on Prevention and Eradication of Money Laundering Crime.

Dhana Widyatmiko allegedly owned some businesses to commit money laundering, among them PT. Mitra Modern Mobilindo (car selling-buying), PT. Bangun Bumi Persada (real estate), PT. Trisula Artamega (trading), land parcels of Rp4.5 billion value, minimarket, and broiler breeding. In addition, a bank account of Rp97 billions was revealed. Dhana allegedly owned a fortune of Rp60 billions.

DhanaWidyatmika case is now being dealt with by General Attorney. However, other related cases that involve top-ranking officers of Finance Department and with greater amount of money than Dhana case's, have not been touched yet by law enforcement officers.

In attempt to answer, resolve the cases and to prevent the repetition of similar cases in the future, the government has taken some preventive steps, among others, 
the enactment of Law Number 21 of 2011 on Financial Service Authority (OJK), as a supplement or complement of those legislations with the similar functions and goals as that of Law on OJK, that is law on Bank Indonesia. In Law No. 21 of 2011 an authority was specially delegated to 0JK investigators to carry our investigations of OJK crimes. The functions and goals of Law on Bank Indonesia are among others to protect the interests of financial service customers in community. However, although the Law on Bank Indonesia has been long prevailing, protection of customers was still weak, as shown above.

In addition, Law on Financial Service Authority stipulates that the functions of financial service authority include also supervision of banks, whereas Law on Bank Indonesia, Article 8 letter c says that: To achieve the goals as intended by Article 7, Bank Indonesia has duties as follows: c. to regulate and supervise banks. Thus, there is an overlapping in the supervision of $0 \mathrm{JK}$, especially in banking sector. Likewise, OJK investigators would face a similar problem in the future, because there will be an overlapping with pre-existing other investigators, namely, attorney, police, and KPK's investigators.

From the description above, there arises a question to study, that is: To the extent of which the effectiveness of OJK investigators in handling financial service crimes in Indonesia?

In addressing the question above and to answer the problem formulated, a normative/juridical-normative legal research was used. The data obtained was analyzed by a descriptive-qualitative method. A descriptive-qualitative analysis is a data analysis method that groups and selects primary data in form of laws, and then related to theories, principles, and legal norms that are obtained from library study so as to find out an answer of the problem formulated.

The benefit of this writing is that it would be useful for legal science in particular and science in general.

\section{Frame of Thought}

The school of natural law is grounded in Aristotle's philosophical thought, which explains the definitions of justice according to law and according to nature. Natural law prevails across the whole spaces and it is unwritten. Furthermore, the relation between natural law and positive (prevailing) law is stated. Aristotle says that natural law is of higher degree than positive one. It fills out the shortcomings of positive law. It brings about fairness and moderates any general provision contained in legislations by taking the certain condition of every problem into account. However, it is not to say that just according to fairness is unjust according to law, rather than fairness renders perfection. ${ }^{1}$

After Aristotle, the thinking on natural law has been developing further. Thomas Aquinas is one of the thinkers of natural law after Aristotle whose thoughts were born in medieval era with great influence particularly among Catholic Churches, even till $21^{\text {st }}$ century, as can be seen in the renewal of his philosophy by those lawyers who uphold Catholic religion, called Neo-Thomistist school. Unlike M.T. Cicero, Thomas Aquinas distinguishes between six types of law, namely: eternal law (lexaeterna),

${ }^{1}$ Roscoe Pound, Pengantar Filsafat Hukum (Introduction to Legal Philosophy), Jakarta, Bharata,1972, p. 14. 
natural law (lexnaturalis), human law (lexhumana), divine law (lexdevina), law that Church imposes to Christians (lexecclesiastica), and law of passions, passionate drives in ourselves that stimulate us to pray (lexconcupiscential). In the medieval time, one of the characteristics of natural law was that it was taken as originated in Divine ratio.

Furthermore, the diversity and manifestation natural law can be seen in Enlightenment (Aufklarung) Age. Thomas Hobbes defines natural law as a compilation of rules to apply as a guide for one's advancement according to its rational aspirations, if he or she can recognize perfectly all conditions that cover it and not shaken at all by impulsive feelings and presumptions. Therefore, according to the opinion of most people, if humans really act so, the rules of natural law hypothetically declare requirement as a basis that enable basic human behaviors to create a solid government. The rules don't determine value customs, but rather they prescribe causally the precepts of law and moral. Moreover, Thomas Hobbes maintains that the first fundamental natural law is to seek peace and to follow it. Human is instructed to seek peace and justice, in line with Aristotle's thoughts.

As for the thoughts of positive law/recht positivisme, this positivism school highly honors written law. It assumes that there is no legal norm outside positive law, all affairs in community being stipulated in written laws. ${ }^{2}$

The most outstanding proponent of this school is Hans Kelsen. According to him, pure legal theory is positive law. This is a theory on general positive law, not an interpretation of a certain national or international legal norm, but it proposes a theory of interpretation. Kelsen's opinion on law characterizes strongly its positivist character. Kelsen see positive law as the only law, and that law should be actually separated from all influences of non-legal elements, such as moral, political, economical, and sociological. He, besides from being well-known as a pioneer of pure legal theory, is credited for developing a stratum theory (stuffen theory) that Adolf Merkl initially proposed. The theory sees law as a system comprising a pyramidshaped arrangement of norms. The lower norms receive their force from the higher ones. The higher a norm is, the more abstract its nature will be, and reversely, the lower its position, the more concrete the norm will be. The highest norm is called by Kelsen as Grundnorm or basic norm. Such opinion is no longer relevant in current modern era. It is impossible for us to make law as an "autonomous object" isolated altogether from economic, politic, social, and cultural influences. Law is not in a vacuum, but rather it is constantly interacting with its surroundings, especially in this current globalization era. Likewise, in Law on OJK that stipulates separately on investigators, that is, by creating and delegating an authority of investigation of OJK crimes to separate investigator outside theexisting investigators, namely: attorney, police, and KPK, intended to make a balance between the legal goals of achieving justice and of achieving legal certainty.

\section{III.Discussion}

From the frame of thought above, we can derive a meaning, that is, law is actually created simply to generate justice, as well as legal certainty. As for the law intended to achieve a justice in community, Muchtar Kusumaatmadja depicts it in a definition of law he proposes:

\footnotetext{
${ }^{2}$ Roelan Saleh, Mengadili Sebagai Pergaulan Kemanusiaan (Adjudication as Humane Interaction). Jakarta, AksaraBaru, 1983, p. 77.
} 
Law is the whole principles and norms that rules human association in community that is intended to maintain order and to achieve justice, and also includes those institutions and processes that realize the application of the norms as a reality in community. ${ }^{3}$

By the definition, Muchtar Kusumaatmadja underlines that order should be created firstly in a community before justice can be achieved, because it is impossible there is a justice if the community is not orderly. That is, the community should abide with law, both material and formal one. Meant by order here includes order in trial processes, from investigation, pre-prosecution, prosecution, trial, and execution, as well as the processes and resolutions of OJK crime cases.

Concerning investigation, Article 1 point 1 of KUHP (Indonesian Criminal Code) stipulates that investigator is Republic of Indonesia police officers or certain civil servants who are delegated with special authorities by law to carry out investigation. The appointment of an officer to be a police investigator is based on the assignment of Republic of Indonesia Head of Police.

The authority of assigning the investigator may be delegated by the Head of Police to a police officer of Republic of Indonesia. Meanwhile, the appointment of a civil servant investigator shall be conducted by Minister upon a recommendation by the Department to which the civil servant belongs. The Minister shall, before making an appointment, firstly hear the considerations of General Attorney and Head of Police. And the authority of appointment may be delegated by the Minister to an officer he or she assigns. (Article 2 (6) PPRI No. 27/1983.).

The appointment of a police-originated person to be an assistant investigator is made by Republic of Indonesia Head of Police upon a recommendation by his or her commander or leader, whereas the appointment of a civil servant-originated person to be an assistant investigator is delegated to Republic of Indonesia Police Officer.

(1) Investigation is an action during a preliminary examination to search evidences on a crime;

(2) Investigation is carried out by:

a. Investigator who is a State Police officer of a rank of $2 \mathrm{~d}$ lieutenant or above;

b. Assistant investigator who is a State Police officer of a rank of $2 \mathrm{~d}$ lieutenant or sergeant major and special police members who are, upon a recommendation of their commander or Head of the Civil Agencies, appointed by Republic of Indonesia Head of Police.

By special police is intended as those officers of certain agencies that are delegated with special police authorities by law.

In addition, there are also special crime investigator, such as special crime investigator, that is, attorney and KPK who carry out investigation on corruption special crimes.

Such is the Law of Financial Service Authority that provides for the separate procedure especially on investigation. It will give a rise to a question on, Will an investigation by OJK investigator take place in the same crime, where both rights and authorities of investigation on 0JK crime are possessed by other investigators. This situation will apparently not be in concordance with an

${ }^{3}$ P. Sitorus, Pengantar Ilmu Hukum (Introduction to Law), Bandung, Pasundan Law Faculty, Alumnus Press, 1998, p. 94 
integrated criminal justice system, one which recognizes an integration of the investigators of crimes. One of the pillars of an integrated handling system is that there should be coordination between investigators involved. ${ }^{4}$

The existence of $0 \mathrm{JK}$ investigators will trigger struggles between the investigators to investigate 0JK crimes and there will be some overlapping that eventually generates ne bis in idem.

Financial Service Authority (OJK) is a self-sufficient, independent institution that is free of other interference. It has some functions, duties, and authorities of regulation, supervision, examination, and investigation in banking, capital market, insurance, pension fund, financing institutions, and other financial service institution sectors. Thus, it covers investigations on corruption, drug trade, weapon and human trafficking, smuggling, tax, capital market, and insurance industry crimes. Those crimes can be investigated by 0JK investigator if there are any indications of crime.

Therefore, OJK investigators have wide authorities, besides from carrying out investigations, which other investigators have not.

The investigations of financial service crimes are provided in Law on 0JK, Article 49, as follows:

(1) Besides from Republic of Indonesia Police Investigator Officer, certain civil servant officers whose duties and responsibilities scope includes the supervision of financial service sector in OJK area are delegated with some special authorities as investigators an intended in KUHAP (Criminal Code of Procedures).

(2) The civil servants as intended in Article 27 paragraph (2) may be appointed as Civil Servant Investigator as intended by paragraph (1) above.

(3) Civil Servant Investigator as intended by paragraph (1) have the following authorities:

a. to receive report (information), notification, or complaint from anyone about any crime in financial service sector;

b. to carry out an investigation of the accuracy of a report or information relating to a crime in financial service sector;

c. to carry out an investigation of anyone who allegedly committed or be involved in a crime in financial service sector;

d. to summon, examine, and ask information and evidence objects from anyone who allegedly committed or are witness in a crime in financial service sector;

e. to carry out examinations of books, records, and other documents relating to a crime in financial service sector;

f. to carry out rummages in certain places where supposedly there are evidence objects in forms of books, records, and other documents, and to carry out seizure of any objects that may be made as an evidence in a criminal case in financial service sector;

g. to ask data, documents, or other evidence tools, either printed or electronic, to an operator of telecommunication service;

${ }^{4}$ BardaNawawiArief, Bunga Rampai Kebijakan Hukum Pidana (Selected Writings in Policy of Criminal Law), First Edition, Bandung, Penerbit PT. Citra AdityaBakti, 1996, p. 61 . 
h. to ask, under certain conditions, authorized officer to do prevention on those who allegedly committed a crimes in financial service sector according to legislations;

i. to ask for aid from other law enforcement officers;

j. to ask for information from a relevant bank on the financial condition of anyone who allegedly committed or be involved in a violation of legislations in financial service sector;

k. to blockade the bank or other financial institution account of anyone who allegedly committed or be involved in a crime in financial service sector;

l. to ask for an aid of expert in attempt to implement a duty of crime investigation in financial service sector; and

$\mathrm{m}$. to set the beginning and the end of a termination of investigation.

The investigator as intended in Article 49 shall deliver the results of investigation to Attorney for prosecution and the Attorney shall follow up and decide on the follow up of the results of the investigation according to his or her authority in no more than 90 (ninety) days since the receipt of the results of investigation as intended in paragraph (1).

The authority of 0JK investigator is the same as that of other investigators on all crimes relating to financial service as provided for in banking, capital market, insurance, pension fund, and financing institution sectors. Meanwhile, the investigators for banking crimes already exist, namely police, attorney, and KPK.

Police as banking crime investigator is stipulated in Law No. 8 of 1981 on KUHAP, Article 6 paragraph (1) a. Investigator is Republic of Indonesia Police. In addition, police as investigator is also provided for in Law No. 2 of 2002 on Republic of Indonesia Police, Article 14 paragraph (1) a: "To conduct inquiry and investigation of all crimes according to KUHAP and other legislations."

Therefore, police as investigator has a right and authority to conduct investigation of all crimes, including ones in financial service sector (banking, etc.).

Likewise, attorney is also investigator with an authority to conduct investigation of certain crimes, such as corruption, as provided for in Law Number 16 of 2004 on Republic of Indonesia General Attorney, Article 30 paragraph (1) d. That is, In criminal area, general attorney has a duty and authority to conduct investigations on certain crimes based on law.

Thus, if there were any indication of corruption crime in financial service sector (banking sector, etc.) then attorney has an authority to conduct investigation. Likewise, KPK investigator has an authority of investigation of corruption crimes, as provided for in Law Number 30 of 2002 on Corruption Eradicating Commission, Article $6 \mathrm{c}$ ): "The duties of Corruption Eradicating Commission are: to conduct inquiry, investigation, and prosecution on corruption crimes."

Thus, KPK investigators have also authority in banking sector and other financial service authority, if there are indications of corruption crime in the sectors. With the investigatory authority of $0 \mathrm{JK}$ investigators, there is diversity in investigators and it causes more overlapping of investigations for certain crimes, that is, ones provided for outside KUHAP. 
Lingering BLBI case, and also Bank Century case, that have been dealt by KPK, police, and attorney investigators, could not accommodate people's aspirations completely until now. The most current case where investigations are overlapping is SIM (driving license) simulator, which is handled simultaneously by police and KPK investigators. Whether OJK investigators would be effective in conducting crime eradication in OJK area? The question proposed early in this writing should be proved in the future, because the authorities of its investigation will barely be done.

\section{Conclusion}

1. In order to protect people against financial service crimes, a law on financial servicewas enacted, that is, Law Number 21 of 2011. The duties and authorities of OJK are, among others, to supervise financial service activities. In addition, OJK also has an authority to handle financial service crimes, that is, by creating separate investigators, that is $0 \mathrm{JK}$ investigators outside the pre-existing investigators, such as police, attorney, and KPK investigators.

2. The enactment of Law Number 21 of 2011 on Financial Service Authority that provides for a separate investigator, investigations would likely overlap, both in general crime investigations and in special crime investigations. Because the crimes taking place in Financial Service Authority have been provided for in some pre-existing legislations that also provide for investigators with a right to conduct investigation.

Police as crime investigator-banking-is stipulated in Law No. 8 of 1981 on KUHAP, Article 6 paragraph (1) a. Investigator is Republic of Indonesia Police. In addition, police as investigator is also provided for in Law No. 2 of 2002 on Republic of Indonesia Police, Article 14 paragraph (1) a: "To conduct inquiry and investigation of all crimes according to KUHAP and other legislations."

Therefore, police as investigator has a right and authority to conduct investigation of all crimes, including ones in financial service sector (banking, etc.).

Likewise, attorney is also investigator with an authority to conduct investigation of certain crimes, such as corruption, as provided for in Law Number 16 of 2004 on Republic of Indonesia General Attorney, Article 30 paragraph (1) d. That is, In criminal area, general attorney has a duty and authority to conduct investigations on certain crimes based on law.

Thus, if there were any indication of corruption crime in financial service sector (banking sector, etc.) then attorney has an authority to conduct investigation. Likewise, KPK investigator has an authority of investigation of corruption crimes, as provided for in Law Number 30 of 2002 on Corruption Eradicating Commission, Article $6 \mathrm{c}$ ): "The duties of Corruption Eradicating Commission are: to conduct inquiry, investigation, and prosecution on corruption crimes."

Thus, KPK investigators have also authority in banking sector and other financial service authority, if there are the indications of corruption crime in the sectors.

3. As for the effectiveness of Financial Service Authority's investigators, it should be proved yet in the future, because the authority of Financial Service Authority's investigators is not yet implemented until now. Therefore, its results and effectiveness could not be measured yet. 


\section{Bibliography}

Adji, Oemar Seno, (1976), Hukum (Acara) Pidana dalam Prospeksi, Jakarta. Erlangga. Bonn, E. Sosrodanukusumo, tt.,Tuntutan Pidana. Djakarta: Penerbit "Siliwangi”.

Hamzah, Andi, (2006), Hukum Acara Pidana Indonesia, Jakarta.SinarGrafika.

Nawawi Arief, Barda, (1996), Bunga Rampai Kebijakan Hukum Pidana, Cetakan Kesatu. Bandung, Penerbit PT. Citra Aditya Bakti.

Pound, Roscoe, (1972), Pengantar FilsafatHukum, Jakarta. Bharata.

Saleh, Roelan, (1983), Mengadili Sebagai PergaulanKemanusiaan. Jakarta :Aksara Baru.

Sitorus, P., (1998), Pengantar Ilmu Hukum (dilengkapitanyajawab,Pasundan Law Faculty. Bandung. Alumnus Press.

Soedjono D., (1982), Pemeriksaan Pendahuluan Menurut KUHAP. Bandung: Alumni.

Tahir, Hadari Djenawi, (1981), Pokok-Pokok Pikiran dalam KUHAP. Bandung: Alumni.

Tanusuboto, S., (1983), Peranan Praperadilan dalam Hukum Acara Pidana.Bandung : Alumni.

Tresna, R., tt., Komentar HIR. Djakarta: PradnyaParamita.

\section{Regulations:}

Undang-Undang Nomor 8 Tahun 1981, tentang Hukum Acara Pidana.

Undang-Undang Nomor 31 Tahun 1999, tentang Pemberantasan Tindak Pidana Korupsi.

Undang-Undang Nomor 21 Tahun 2011, tentang Otoritas Jasa Keuangan. 